\title{
Thermal Decomposition Kinetics of Rare Earth Minerals in Tailings with Addition of MgO
}

\author{
Yan Zhou ${ }^{1,2}$, Shizhe Song ${ }^{1,2}$, Jianxing Liu ${ }^{1,2}$, Gongjin Cheng ${ }^{1,2}$, He Yang ${ }^{1,2}$ and Xiangxin Xue ${ }^{1,2, *}$ \\ 1 School of Metallurgy, Northeastern University, Shenyang 110169, China; yanzhouchn@gmail.com (Y.Z.); \\ 1801573@stu.neu.edu.cn (S.S.); liujianxing@smm.neu.edu.cn (J.L.); chenggj@smm.neu.edu.cn (G.C.); \\ yangh@smm.neu.edu.cn (H.Y.) \\ 2 Liaoning Key Laboratory of Metallurgical Resources Recycling Science, Shenyang 110169, China \\ * Correspondence: xuexx@mail.neu.edu.cn; Tel.: +86-24-8368-7719
}

check for updates

Citation: Zhou, Y.; Song, S.; Liu, J.;

Cheng, G.; Yang, H.; Xue, X. Thermal Decomposition Kinetics of Rare Earth Minerals in Tailings with Addition of MgO. Metals 2021, 11, 701. https:// doi.org/10.3390/met11050701

Academic Editors: Jae-chun Lee and Jungshin Kang

Received: 23 March 2021

Accepted: 22 April 2021

Published: 25 April 2021

Publisher's Note: MDPI stays neutral with regard to jurisdictional claims in published maps and institutional affiliations.

Copyright: (c) 2021 by the authors. Licensee MDPI, Basel, Switzerland. This article is an open access article distributed under the terms and conditions of the Creative Commons Attribution (CC BY) license (https:// creativecommons.org/licenses/by/ $4.0 /)$.

\begin{abstract}
Due to the advantage in deactivating fluorine and enhancing the decomposition of rare earth (RE) minerals, $\mathrm{MgO}$ was applied to the magnetizing roasting of Bayan Obo tailings in this work. The effects of $\mathrm{MgO}$ dosages, roasting temperature, and holding time on the decomposition rate of $\mathrm{RE}$ minerals were experimentally studied. With a MgO dosage of $10 \mathrm{wt} . \%$, the decomposition rate of RE minerals reached $98.09 \%$ at $750{ }^{\circ} \mathrm{C}$. The phase composition of roasted samples was characterized by XRD and SEM-EDS. The incomplete decomposition rate was investigated with the observation of leaching residual by SEM-EDS. The decomposition kinetics of the RE minerals with the addition of $\mathrm{MgO}$ was analyzed with the Ginstling-Brundshtein model, where the reaction rate was controlled by chemical reaction.
\end{abstract}

Keywords: kinetics; rare earth; $\mathrm{MgO}$ roasting; Bayan Obo tailings; thermal decomposition; magnetizing roasting

\section{Introduction}

Rare earth (RE) elements, namely lanthanum (Ln), scandium (Sc), and yttrium (Y), are irreplaceable strategic resources for innumerable applications owing to their chemical, catalytic, electrical, magnetic, and optical properties [1-4]. The Bayan Obo ore deposit, located in Inner Mongolia, China, which is a well-known polymetallic ore with more than 40 million tons of RE reserves (count as RE oxides) [5], was initially developed as an iron ore mine in 1927 and did not begin RE production until decades later [6]. Unfortunately, the utilization rate of mined RE elements is only 10-15\% [1], and approximately 150 million tons of tailings with an average RE oxides content of $8.85 \%$ have been abandoned in a tailings dam [7]. The tailings occupy an area of $11.5 \mathrm{~km}^{2}$ and cause extensive waste and serious environmental pollution [8]. As the global demand for RE elements increasing, the environmental and economic benefits of recycling RE elements from the tailings attracts great interests.

The RE minerals in Bayan Obo tailings, composed primarily of bastnaesite $\left(\mathrm{RECO}_{3} \mathrm{~F}\right)$ and monazite $\left(\mathrm{REPO}_{4}\right)$, are recognized as intractable minerals in hydrometallurgy [9]. Commercially, the technologies of roasting with sulfuric acid and treatment in sodium hydroxide are mainly applied to decompose the RE minerals in concentrate, but are uneconomical for processing the tailings [2,9]. These methods also lead to environmental pollution, such as emissions of $\mathrm{HF}$ and $\mathrm{SO}_{2}$, plenty of waste-water [2]. In order to extract RE directly from tailings, numerous clean methods have been proposed by researchers to decompose the RE minerals. In our previous study [6], the method combining magnetizing roasting and $\left(\mathrm{NH}_{4}\right)_{2} \mathrm{SO}_{4}$ activation roasting was developed to recover Fe and RE elements from the Bayan Obo tailings. However, the recovery rate of RE reached $76-83 \%$ since $\mathrm{REPO}_{4}$ in tailings was not completely decomposed. According to the study of Yuan et al. [10], 
$99.87 \%$ of RE minerals in tailings were decomposed at $750{ }^{\circ} \mathrm{C}$ via adding $\mathrm{CaO}$. Meanwhile, the addition of $\mathrm{CaO}$ suppressed the emission of F-containing waste-gas during roasting.

Meanwhile, $\mathrm{MgO}$ was initially used as an additive to deactivate fluorine prior to chloride roasting and to improve the recovery of $\mathrm{RE}$ [11]. In the presence of $\mathrm{MgO}, \mathrm{F}$ was fixed in form of $\mathrm{MgF}_{2}$, which also suppresses the emission of F-containing waste-gas. The studies $[12,13]$ reported a technique that the mixed concentrate of $\mathrm{RECO}_{3} \mathrm{~F}$ and $\mathrm{REPO}_{4}$ was roasted with $\mathrm{MgO}$ and $\mathrm{RE}$ elements were subsequently recovered via chlorination roasting, and it was found that $\mathrm{MgO}$ could enhance the decomposition of RE concentrates. However, the effect of $\mathrm{MgO}$ on the decomposition of RE minerals has not been studied in depth, then its application to process RE tailings was rarely reported.

In this work, the magnetizing roasting process which has been studied in our previous work [6] was improved by adding $\mathrm{MgO}$ and by increasing roasting temperature. The effects of $\mathrm{MgO}$ dosages, roasting temperature, and holding time on the decomposition rate were investigated. The phase compositions of the roasting products were characterized by X-ray diffusion (XRD) and scanning electron microscopy \& energy dispersive X-ray spectroscopy (SEM-EDS). Subsequently, the kinetics and activation energy of thermal decomposition of RE minerals were analyzed based on the experimental data. This study is expected to provide a clean method for the recovery of RE minerals in tailings.

\section{Experimental}

\subsection{Materials}

The starting material in this study is the Bayan Obo tailing, from the Ore-Dressing Plant, Baotou Steel (Group) Co. (Baotou, Inner Mongolia, China). Its main chemical composition is listed in Table 1 . The volume fraction of the particles with sizes lower than $74 \mu \mathrm{m}$ is $65.66 \%$. The pulverized coal with a carbon content of $83 \mathrm{wt}$. \% was used as reducing agent, and the analytical reagents of $\mathrm{MgO}, \mathrm{HCl}$, and $\mathrm{H}_{2} \mathrm{O}_{2}$ were purchased from Sinopharm Chemical Reagent Co., Ltd. (Shanghai, China). All the solutions in the experiments were prepared with distilled water.

Table 1. Chemical composition of the tailing sample (wt.\%).

\begin{tabular}{cccccccc}
\hline $\mathbf{F e}_{\text {total }}$ & $\mathbf{R E O}$ & $\mathbf{N b}_{\mathbf{2}} \mathbf{O}_{\mathbf{5}}$ & $\mathrm{Sc}$ & $\mathbf{C a O}$ & $\mathrm{SiO}_{2}$ & $\mathbf{B a O}$ & $\mathbf{M g O}$ \\
\hline 13.06 & 7.09 & 0.11 & 0.01 & 30.34 & 11.71 & 4.13 & 3.32 \\
\hline $\mathbf{A l}_{\mathbf{2}} \mathbf{O}_{\mathbf{3}}$ & $\mathbf{M n O}$ & $\mathrm{TiO}_{\mathbf{2}}$ & $\mathbf{F}$ & $\mathbf{S}$ & $\mathbf{P}$ & $\mathbf{N a}_{\mathbf{2}} \mathbf{O}$ & $\mathbf{K}_{\mathbf{2}} \mathbf{O}$ \\
\hline 1.39 & 1.15 & 0.80 & 12.50 & 1.66 & 1.39 & 1.03 & 0.52 \\
\hline
\end{tabular}

\subsection{Procedures and Characterization}

The flowchart of the roasting procedure is shown in Figure 1a. Firstly, $10 \mathrm{~g}$ of tailings, $0.067 \mathrm{~g}$ of pulverized coal, and $\mathrm{MgO}$ powder with a mass ratio varying between $0-25 \mathrm{wt} . \%$ were mixed in a sealed tank for $5 \mathrm{~h}$. Subsequently, the mixtures were pressed into cylinders with a diameter of $25 \mathrm{~mm}$ under a compressive force of $58.8 \mathrm{kN}$. The cylindrical sample were sealed in a capped graphite crucible and heated to a preset temperature in a muffle furnace (Shenyang Metallurgical Graphite Factory, Shenyang, China) with a heating rate of $10{ }^{\circ} \mathrm{C} / \mathrm{min}$. After reaching the preset temperature, the samples were held for different time then cooled to room temperature in air. The roasted samples were crushed and ground into powders using a vibration grinding mill. The phase composition of the samples was identified by XRD (X Pertpro, PANalytical B.V., Almelo, The Netherlands) with the (Cu $\mathrm{K} \alpha$ ) radiation of $40 \mathrm{kV}$ and $40 \mathrm{~mA}$. The mineralogical phases of samples were investigated using SEM-EDS (ULTRA PLUS, Carl Zeiss AG, Jena, Germany). It should be noted that the roasting condition in this work was designed according to magnetic separation, since the Bayan Obo tailing contains $13.1 \%$ Fe. So the roasting temperature was adjusted below $800{ }^{\circ} \mathrm{C}$ to avoid the formation of non-magnetic FeO. 


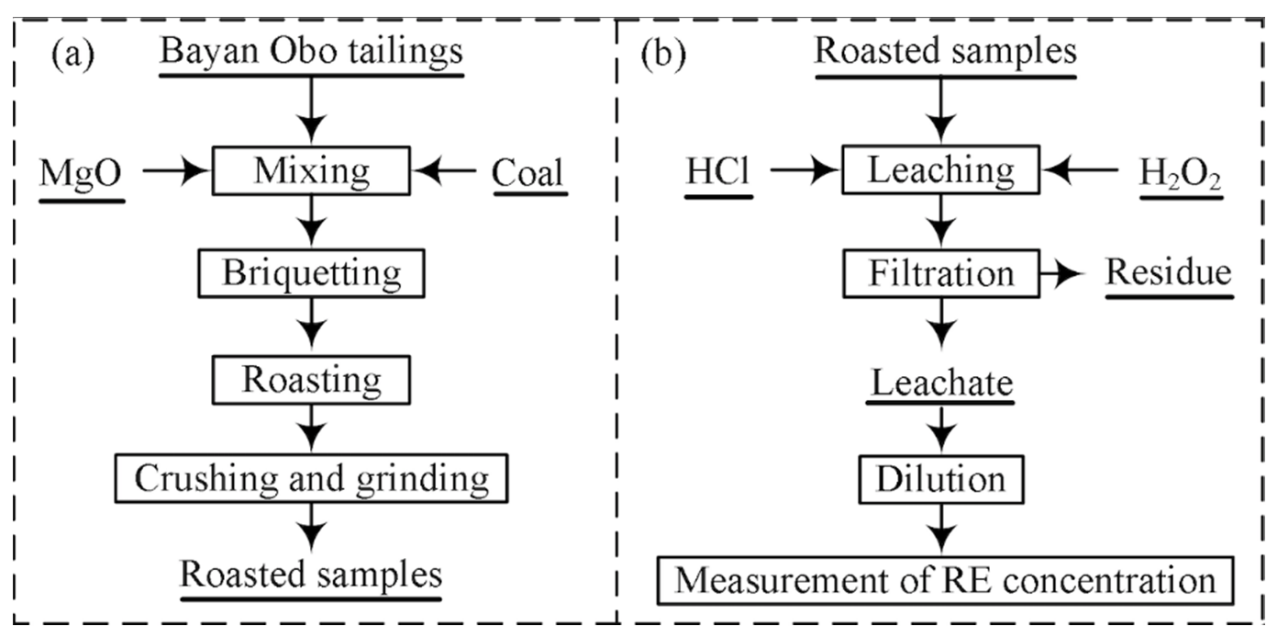

Figure 1. Flowchart of the experimental procedure. (a) roasting procedure, (b) leaching procedure.

The flowchart of the leaching procedure is shown in Figure $1 \mathrm{~b}$. The leaching experiments were carried out in a three-necked flask shown in Figure 2 with a boiling water bath $\left(100{ }^{\circ} \mathrm{C}\right)$. A condensing return tube, an electronically controlled agitator, and a glass thermometer were attached to the three-necked flask, as shown in Figure 2. The roasted sample powders $(1 \mathrm{~g}), 40 \mathrm{~mL}$ of $\mathrm{HCl}$ solution $(6 \mathrm{~mol} / \mathrm{L})$, and $10 \mathrm{~mL}$ of $\mathrm{H}_{2} \mathrm{O}_{2}$ solution (30 wt.\%) were mixed in the flask and then stirred for $30 \mathrm{~min}$. The leachate was separated by vacuum filtration and cooled to room temperature. Subsequently, the leachate was diluted to $500 \mathrm{~mL}$. The leaching residues were collected after drying. The contents of $\mathrm{RE}$ ions in the leachate were determined by inductively coupled plasma optical emission spectrometry (ICP-OES, model: Optima 8300DV, Perkin Elmer Co., Waltham, MA, USA). Since only the decomposed RE minerals could be leached out, the decomposition rate of $\mathrm{RE}$ minerals in the roasted samples was calculated using Equation (1):

$$
\eta=\frac{C \times V}{m \times \omega} \times 100 \%
$$

where $\eta$ is the decomposition rate (\%), $C$ is the concentration of RE elements in leachate $(\mathrm{g} / \mathrm{mL}), V$ is the volume of leachate $(500 \mathrm{~mL}), m$ is the mass of the roasted samples before leaching $(1 \mathrm{~g})$, and $\omega$ is the content of RE elements in the roasted samples (wt.\%).

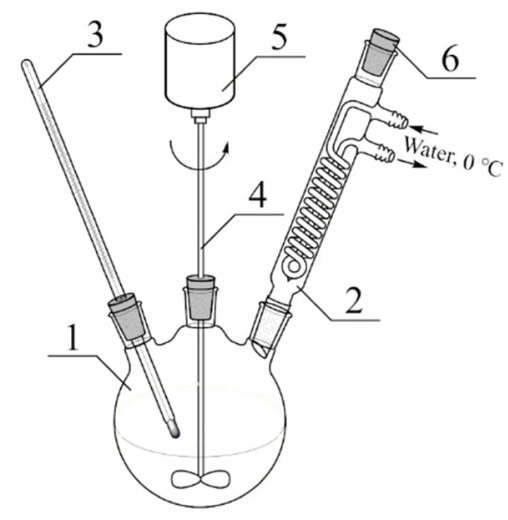

Figure 2. Schematic diagram of the three-necked flask for leaching. 1-three-necked flask, 2-condensing return tube, 3-glass thermometer, 4-agitator, 5-electric motor, 6-plug.

\section{Results and Discussion}

\subsection{Effect of $M g O$ Dosage on Decomposition Rate}

The effect of $\mathrm{MgO}$ dosage on the decomposition rate of $\mathrm{RE}$ minerals was investigated with a constant roasting temperature of $750{ }^{\circ} \mathrm{C}$ and hold time of $120 \mathrm{~min}$, the results 
were summarized in Figure 3. As the dosage of $\mathrm{MgO}$ raising from 0 to $10 \mathrm{wt} \%$, the decomposition rate increased from $95.1 \%$ to $98.1 \%$. Further increase in the MgO dosage beyond the stoichiometric requirement did not enhance decomposition rate, but increased the cost. Therefore, the dosage of $\mathrm{MgO}$ in the following experiments was fixed to $10 \mathrm{wt} . \%$.

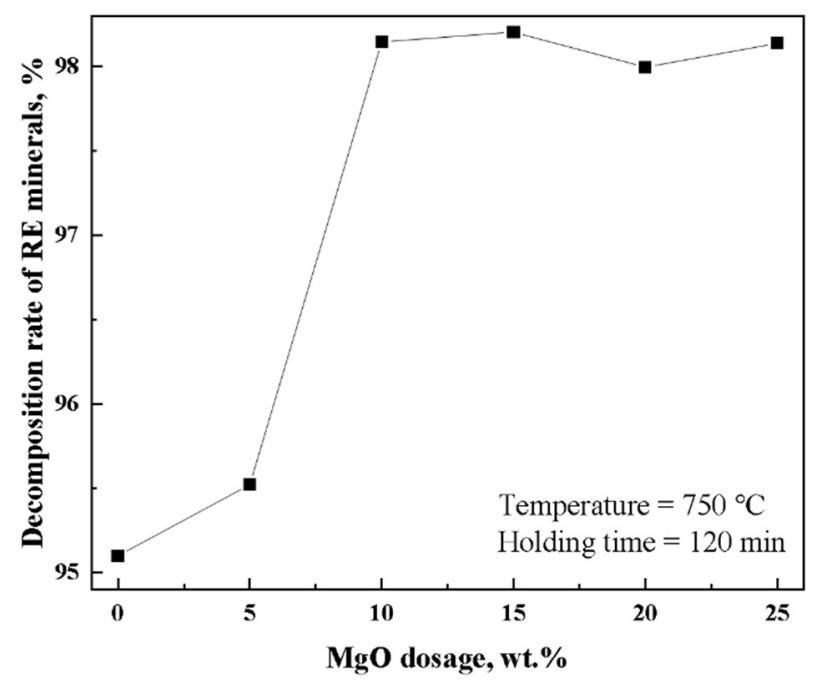

Figure 3. Effect of $\mathrm{MgO}$ dosages on the decomposition rate of $\mathrm{RE}$ minerals.

\subsection{Phase Characterization}

The XRD patterns of the raw tailings and the samples roasted at different temperature are shown in Figure 4.

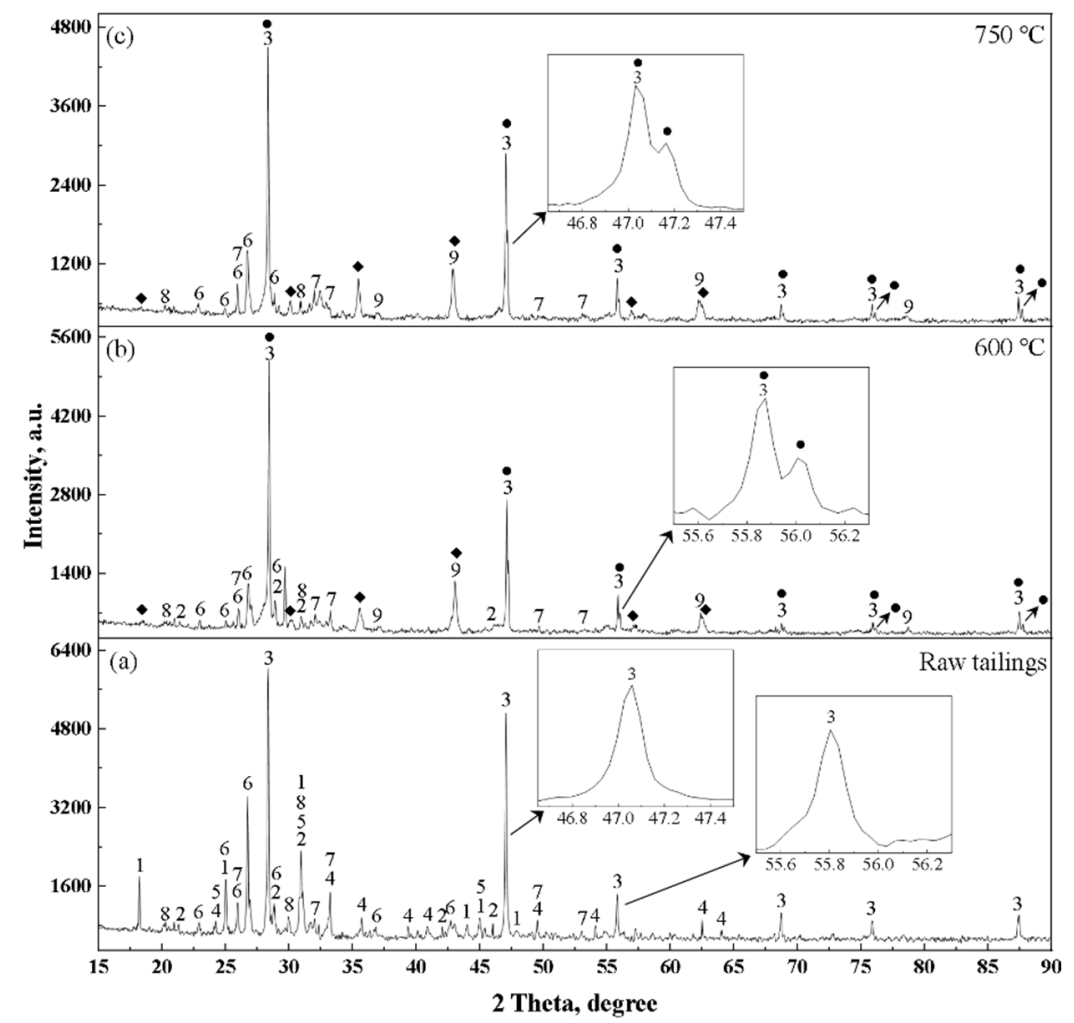

Figure 4. XRD pattern of samples under different conditions: (a)raw tailings, (b) sample of tailings with addition of $10 \mathrm{wt} . \% \mathrm{MgO}$ roasted at $600{ }^{\circ} \mathrm{C}$ for $120 \mathrm{~min}$, (c) sample of tailings with addition of $10 \mathrm{wt} . \% \mathrm{MgO}$ roasted at $750{ }^{\circ} \mathrm{C}$ for $120 \mathrm{~min} .1-\mathrm{RECO}_{3} \mathrm{~F}, 2-\mathrm{REPO}_{4}, 3-\mathrm{CaF}_{2}, 4-\mathrm{Fe}_{2} \mathrm{O}_{3}, 5-\mathrm{CaMg}\left(\mathrm{CO}_{3}\right)_{2}$, $6-\mathrm{BaSO}_{4}, 7-\mathrm{Ca}_{5}\left(\mathrm{PO}_{4}\right)_{3} \mathrm{~F}, 8-\mathrm{Na}(\mathrm{Fe}, \mathrm{Sc}) \mathrm{Si}_{2} \mathrm{O}_{6}, 9-\mathrm{MgO}, \bullet-\mathrm{Fe}_{3} \mathrm{O}_{4}, \bullet-\mathrm{REO}$. 
As shown by Figure 4a, the RE minerals in the tailings are primarily composed of bastnaesite $\left(\mathrm{RECO}_{3} \mathrm{~F}\right)$ and monazite $\left(\mathrm{REPO}_{4}\right)$. Besides, minerals such as fluorite $\left(\mathrm{CaF}_{2}\right)$, hematite $\left(\mathrm{Fe}_{2} \mathrm{O}_{3}\right)$, dolomite $\left(\mathrm{CaMg}\left(\mathrm{CO}_{3}\right)_{2}\right)$, barite $\left(\mathrm{BaSO}_{4}\right)$, apatite $\left(\mathrm{Ca}_{5}\left(\mathrm{PO}_{4}\right)_{3} \mathrm{~F}\right)$, and pyroxene $\left(\mathrm{Na}(\mathrm{Fe}, \mathrm{Sc}) \mathrm{Si}_{2} \mathrm{O}_{6}\right)$ were detected in the tailings. Figure $4 \mathrm{~b}, \mathrm{c}$ show no diffraction peaks of $\mathrm{RECO}_{3} \mathrm{~F}$, indicating the complete decomposition of $\mathrm{RECO}_{3} \mathrm{~F}$. This is consistent with the decomposition temperature of $\mathrm{RECO}_{3} \mathrm{~F}$ reported in the literatures $[10,14]$, which is in the range of $400-600{ }^{\circ} \mathrm{C}$.

The diffraction peaks of $\mathrm{REPO}_{4}$ shown in Figure $4 \mathrm{~b}$ disappeared after rising to $750{ }^{\circ} \mathrm{C}$ in Figure $4 \mathrm{c}$, indicating the decomposition temperature of $\mathrm{REPO}_{4}$ is in the range of $600-750^{\circ} \mathrm{C}$. Due to the similar crystalline structure, the peaks of $\mathrm{CaF}_{2}$ and REO in Figure $4 b, c$ are overlapped, but could be distinguished at a magnified view, as shown by the inset in Figure 4. This is consistent with the data reported in the literature [10]. The REO here represents $\mathrm{Ce}_{2} \mathrm{O}_{3}, \mathrm{Ce}_{0.75} \mathrm{Nd}_{0.25} \mathrm{O}_{1.875}, \mathrm{LaPrO}_{3+}, \mathrm{Pr}_{2} \mathrm{O}_{3}$, or $\mathrm{CeO}_{2}$. As shown in Figure $4, \mathrm{Fe}_{2} \mathrm{O}_{3}$ was reduced to $\mathrm{Fe}_{3} \mathrm{O}_{4}$ by the carbon from coal, and $\mathrm{CaMg}\left(\mathrm{CO}_{3}\right)_{2}$ was thermally decomposed at $600-750{ }^{\circ} \mathrm{C}$. The phases of $\mathrm{CaF}_{2}, \mathrm{BaSO}_{4}, \mathrm{Ca}_{5}\left(\mathrm{PO}_{4}\right)_{3} \mathrm{~F}$, and $\mathrm{NaFeSi}_{2} \mathrm{O}_{6}$ could be still detected after roasting, showing relatively high thermal stability.

Figure 5 shows the results of thermogravimetry and differential scanning calorimetry (TG-DSC) analysis (model: STA449, NETZSCH, Selb, Germany) and differential thermogravimetry (TG-DTG) results for the tailings without and with addition of $\mathrm{MgO}$. It shows two main peaks in both DSC and DTG curves of the two samples. The first endothermic peaks at $525.9^{\circ} \mathrm{C}$ shown in Figure 5a are attributed to the decomposition of $\mathrm{RECO}_{3} \mathrm{~F}$ [14]. The second endothermic peaks at $705.5^{\circ} \mathrm{C}$ were caused by the decomposition of $\mathrm{REPO}_{4}[10,15]$. For the sample with $10 \% \mathrm{MgO}$ addition, the first endothermic peak was broadened, indicating that $\mathrm{MgO}$ addition lowers the decomposition temperature of $\mathrm{RECO}_{3} \mathrm{~F}$. The DTG curves shown in Figure $5 \mathrm{~b}$ exhibit an apparent peak shift, from $523{ }^{\circ} \mathrm{C}$ to $467-520^{\circ} \mathrm{C}$.

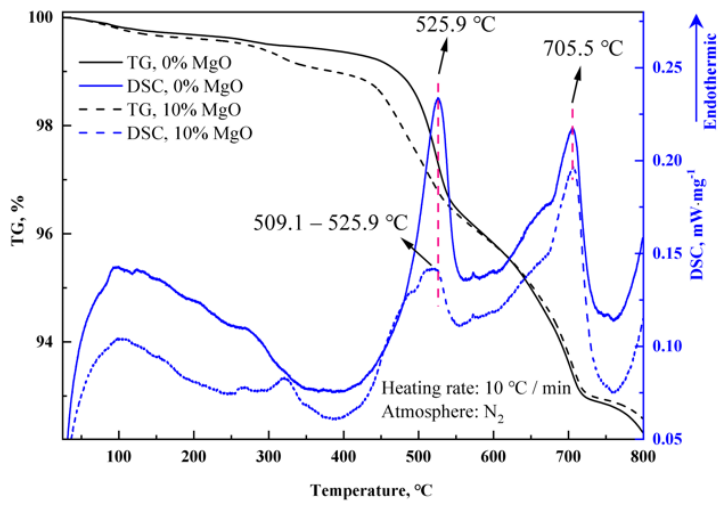

(a)

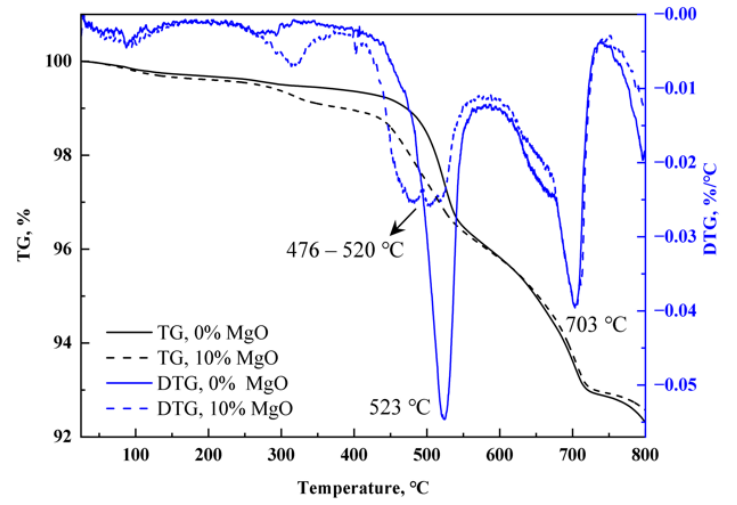

(b)

Figure 5. TG-DSC analysis of the samples without and with addition of MgO: (a) TG-DSC curves, (b) TG-DTG curves.

Figures 6 and 7 and Table 2 show the SEM-EDS results of the sample with $10 \mathrm{wt} . \%$ $\mathrm{MgO}$ roasted at $700{ }^{\circ} \mathrm{C}$ for $120 \mathrm{~min}$. Figure 6a shows that RE oxides (marked as " $\mathrm{C}$ ") were attached to $\mathrm{CaF}_{2}$ particles (marked as " $\mathrm{A}$ "). The EDS analysis results of points " $\mathrm{B}$ " and " $\mathrm{C}$ " exhibit the presence of $\mathrm{Mg}$ and $\mathrm{F}$, which may be due to the reaction shown in Equation (2) [11,16]. The particle shown in Figure $5 \mathrm{~b}$ is the aggregation of $\mathrm{MgO}$ and $\mathrm{RE}$ oxides. $\mathrm{P}$ and $\mathrm{F}$ were detected at points " $\mathrm{D}$ " and " $\mathrm{F}$ ", which are from the reactions shown in Equations (3) and (4) [12,16]. Also, $\mathrm{CaO}$ from the decomposition of $\mathrm{CaMg}\left(\mathrm{CO}_{3}\right)_{2}$, as shown by Equation (5) [17], led to the reactions shown as Equations (6)-(8) $[10,17,18]$ :

$$
\begin{gathered}
2 \mathrm{RECO}_{3} \mathrm{~F}+\mathrm{MgO}=\mathrm{MgF}_{2}+\mathrm{RE}_{2} \mathrm{O}_{3}+2 \mathrm{CO}_{2} \\
2 \mathrm{REPO}_{4}+3 \mathrm{MgO}=\mathrm{RE}_{2} \mathrm{O}_{3}+\mathrm{Mg}_{3}\left(\mathrm{PO}_{4}\right)_{2} \\
\mathrm{MgF}_{2}+\mathrm{Mg}_{3}\left(\mathrm{PO}_{4}\right)_{2}=2 \mathrm{Mg}_{2} \mathrm{PO}_{4} \mathrm{~F}
\end{gathered}
$$




$$
\begin{gathered}
\mathrm{CaMg}\left(\mathrm{CO}_{3}\right)_{2}=\mathrm{CaO}+\mathrm{MgO}+2 \mathrm{CO}_{2} \\
2 \mathrm{RECO}_{3} \mathrm{~F}+\mathrm{CaO}=\mathrm{CaF}_{2}+\mathrm{RE}_{2} \mathrm{O}_{3}+2 \mathrm{CO}_{2} \\
2 \mathrm{REPO}_{4}+3 \mathrm{CaO}=\mathrm{RE}_{2} \mathrm{O}_{3}+\mathrm{Ca}_{3}\left(\mathrm{PO}_{4}\right)_{2} \\
\mathrm{CaF}_{2}+\mathrm{Ca}_{3}\left(\mathrm{PO}_{4}\right)_{2}=2 \mathrm{Ca}_{2} \mathrm{PO}_{4} \mathrm{~F}
\end{gathered}
$$
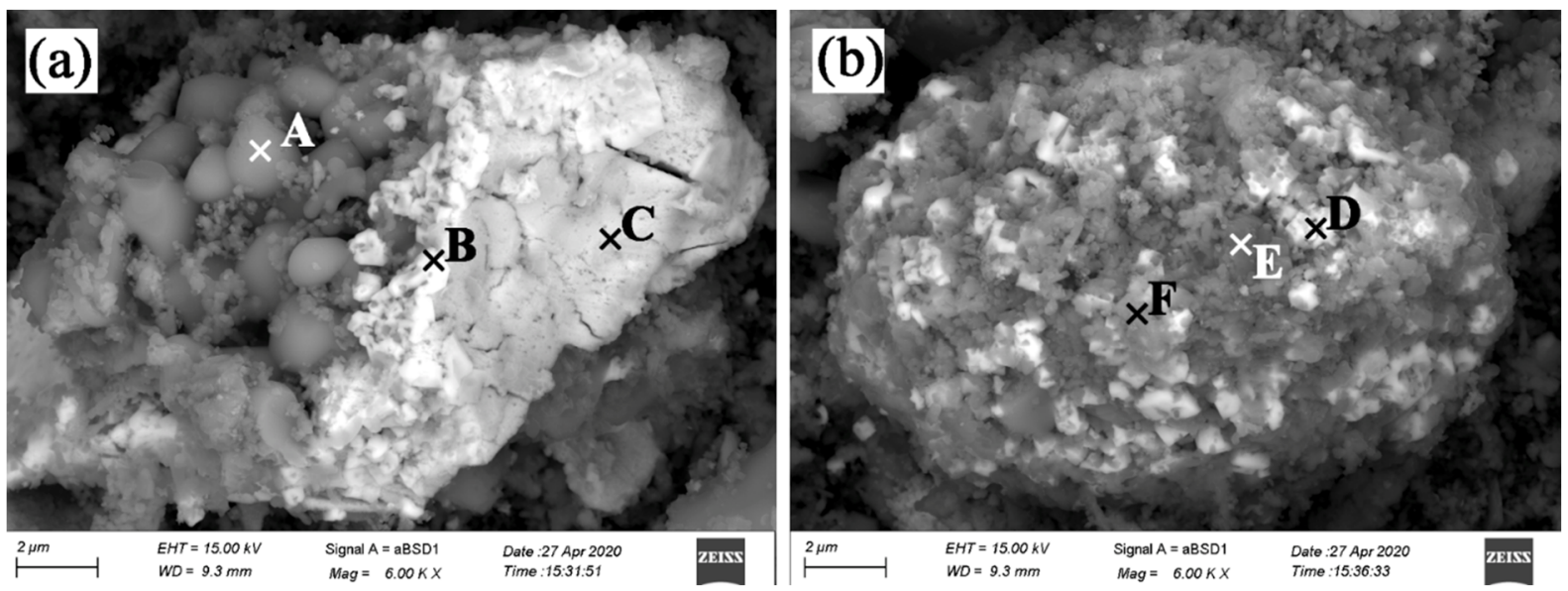

Figure 6. SEM images of the roasted sample of tailings with $10 \mathrm{wt} . \% \mathrm{MgO}$ addition at $700{ }^{\circ} \mathrm{C}$ for $120 \mathrm{~min}(\mathbf{a}, \mathbf{b})$.
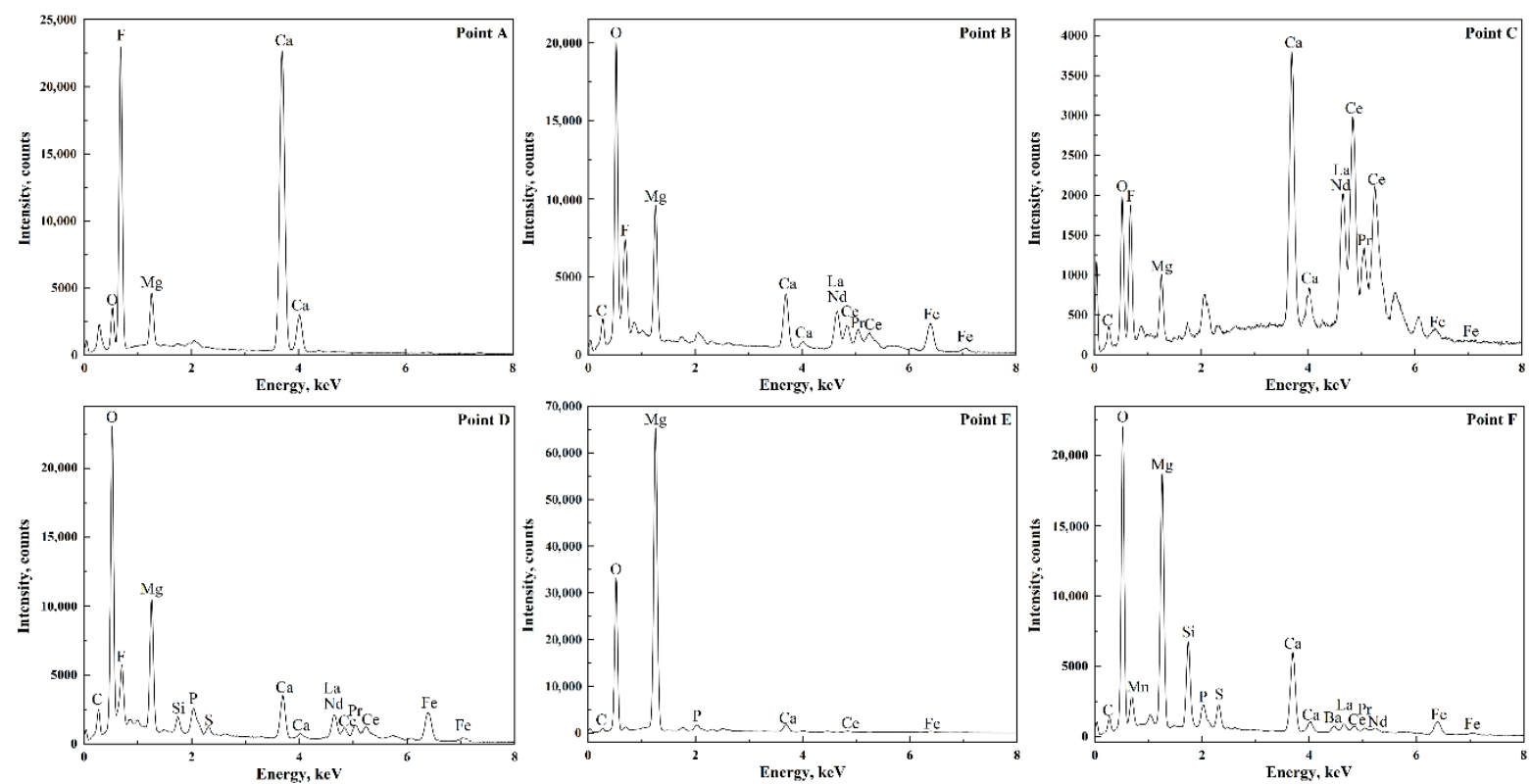

Figure 7. EDS analysis results of points in Figure 6.

\subsection{Effect of Roasting Temperature on Decomposition Rate}

The effects of roasting temperature and holding time on the decomposition rate of RE minerals were investigated with a constant $\mathrm{MgO}$ mass ratio of $10 \mathrm{wt} . \%$. The holding time for roasting varied in the range of $0-120 \mathrm{~min}$. The results are presented in Figure 8, showing that the decomposition rate increased with the temperature and holding time, respectively. 
Table 2. EDS analysis results of points in Figure 6 (wt.\%).

\begin{tabular}{ccccccc}
\hline Element & Point A & Point B & Point C & Point D & Point E & Point F \\
\hline $\mathrm{C}$ & 3.49 & 4.68 & 1.23 & 5.64 & 3.90 & 4.40 \\
$\mathrm{O}$ & 8.10 & 24.56 & 5.25 & 30.06 & 40.18 & 34.51 \\
$\mathrm{~F}$ & 42.98 & 4.05 & 3.57 & - & - & - \\
$\mathrm{Mg}$ & 3.38 & 9.85 & 1.97 & 10.87 & 47.81 & 17.26 \\
$\mathrm{Si}$ & - & - & - & 1.23 & - & 5.89 \\
$\mathrm{P}$ & - & - & - & - & 1.18 & 1.55 \\
$\mathrm{~S}$ & - & - & - & - & - & 2.12 \\
$\mathrm{Ca}$ & 37.95 & 6.04 & 10.50 & 5.62 & 3.05 & 10.76 \\
$\mathrm{Fe}$ & 0.63 & 11.78 & 1.07 & 14.74 & 1.76 & 6.64 \\
$\mathrm{Mn}$ & - & - & - & - & - & 0.57 \\
$\mathrm{Ba}$ & - & - & - & - & 0.99 & 3.86 \\
$\mathrm{La}$ & - & 19.41 & 23.01 & 14.75 & - & 5.42 \\
$\mathrm{Ce}$ & - & 14.12 & 40.05 & 7.86 & 1.15 & 3.05 \\
$\mathrm{Pr}$ & - & 2.19 & 3.70 & 3.19 & - & 1.21 \\
$\mathrm{Nd}$ & - & 3.33 & 9.66 & 6.05 & - & 2.75 \\
\hline
\end{tabular}

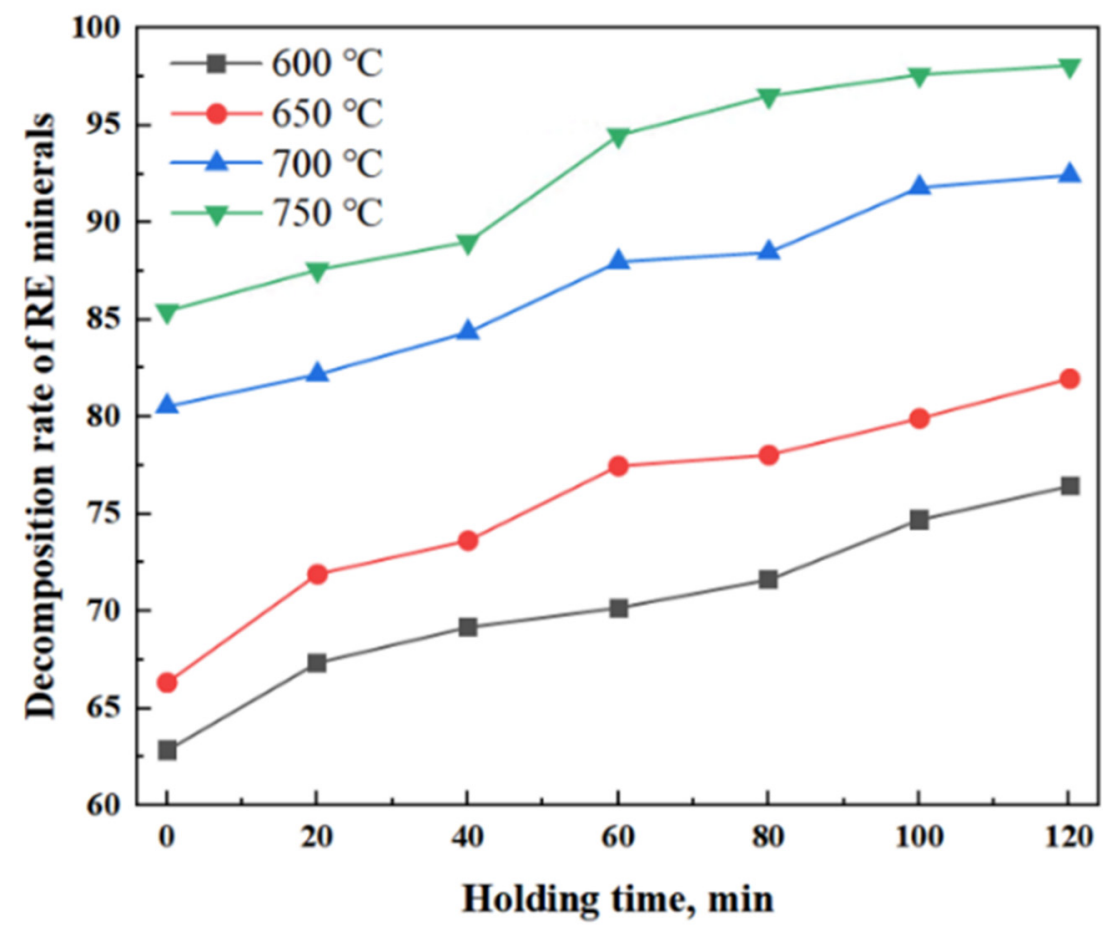

Figure 8. Effect of roasting temperature and holding time on the decomposition rate of RE minerals.

With the hold time of $120 \mathrm{~min}$, the maximum decomposition rates at $600{ }^{\circ} \mathrm{C}, 650{ }^{\circ} \mathrm{C}$, $700{ }^{\circ} \mathrm{C}$, and $750{ }^{\circ} \mathrm{C}$ reached $76.45 \%, 81.97 \%, 92.44 \%$, and $98.09 \%$, respectively. It should be noted that the decomposition rates for all the cases exceeded $60 \%$ during the temperaturerising stage. The SEM-EDS results of the leaching residues are shown in Figures 9 and 10 and Table 3. The $\mathrm{BaSO}_{4}$ particles (marked as " $\mathrm{H}$ ", " $\mathrm{L}$ " and " $\mathrm{N}$ " in Figure 9) and the $\mathrm{Na}(\mathrm{Fe}$, $\mathrm{Sc}) \mathrm{Si}_{2} \mathrm{O}_{6}$ particles (marked as " $\mathrm{J}$ " and " $\mathrm{K}$ " in Figure 9) were detected in all leaching residues. The particles marked as "G" and " $\mathrm{M}$ " in Figure 9 contain $\mathrm{Nb}, \mathrm{Ti}, \mathrm{Fe}, \mathrm{Ce}, \mathrm{Nd}$, and $\mathrm{Ca}$, which belong to niobium minerals such as pyrochlore-group $\left(\mathrm{Ce}_{2} \mathrm{Nb}_{2} \mathrm{O}_{6}(\mathrm{OH})_{2}\right)$, ilmenorutile $((\mathrm{Ti}$, $\left.\mathrm{Nb}, \mathrm{Fe}) \mathrm{O}_{2}\right)$, and eschynite $\left(\mathrm{CeTiNbO}_{6}\right)$, according to the study of Zhang et al. [19]. These undecomposed niobium minerals are the reasons for the decomposition rate of RE minerals not reaching $100 \%$ at $750{ }^{\circ} \mathrm{C}$. While the reason for the low decomposition rate before $750{ }^{\circ} \mathrm{C}$ is the undecomposed $\mathrm{REPO}_{4}$, which was observed in the sample roasted at $600{ }^{\circ} \mathrm{C}$, as shown by the particles marked "I" in Figure 9b. 


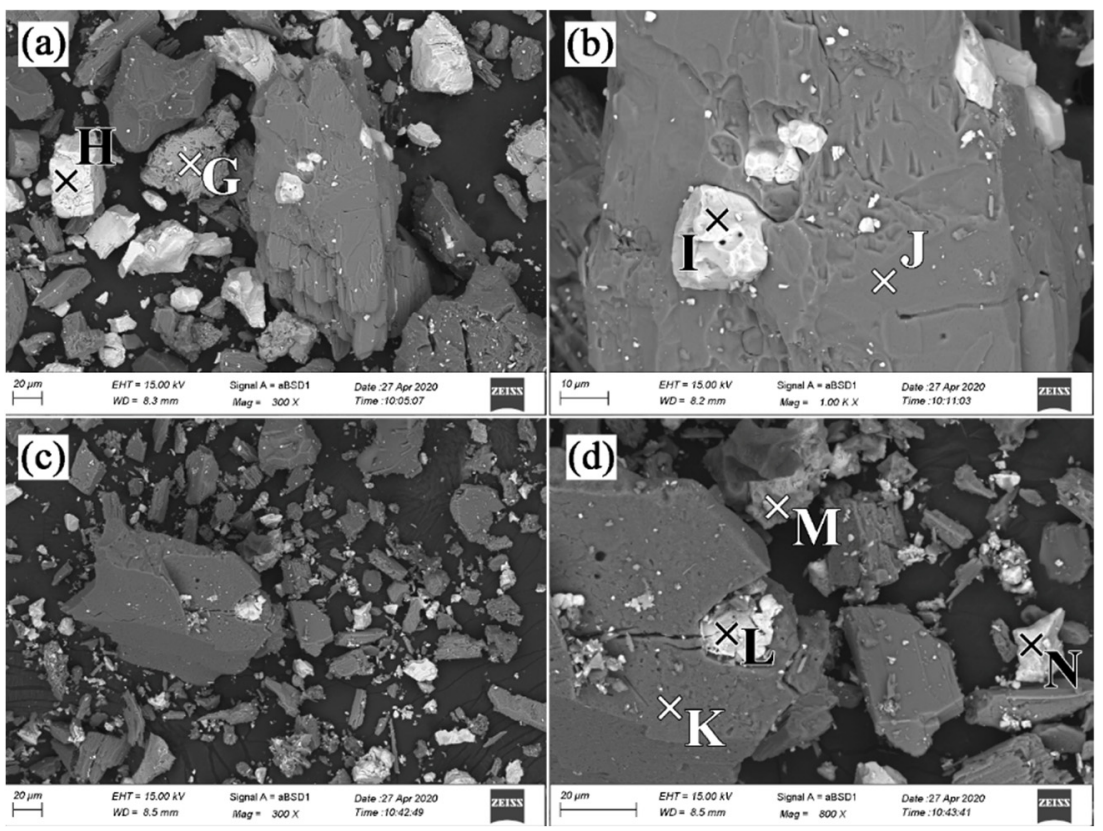

Figure 9. SEM image of the leaching residues of samples roasted at different temperatures for $120 \mathrm{~min}$ : (a,b) $600{ }^{\circ} \mathrm{C}$, (c,d) $750{ }^{\circ} \mathrm{C} ; \mathrm{H}, \mathrm{L}$, and $\mathrm{N}$ are $\mathrm{BaSO}_{4} ; \mathrm{J}$ and $\mathrm{K}$ are $\mathrm{Na}(\mathrm{Fe}, \mathrm{Sc}) \mathrm{Si}_{2} \mathrm{O}_{6} ; \mathrm{G}$ and $\mathrm{M}$ are niobium minerals; $\mathrm{I}$ is $\mathrm{REPO}_{4}$.
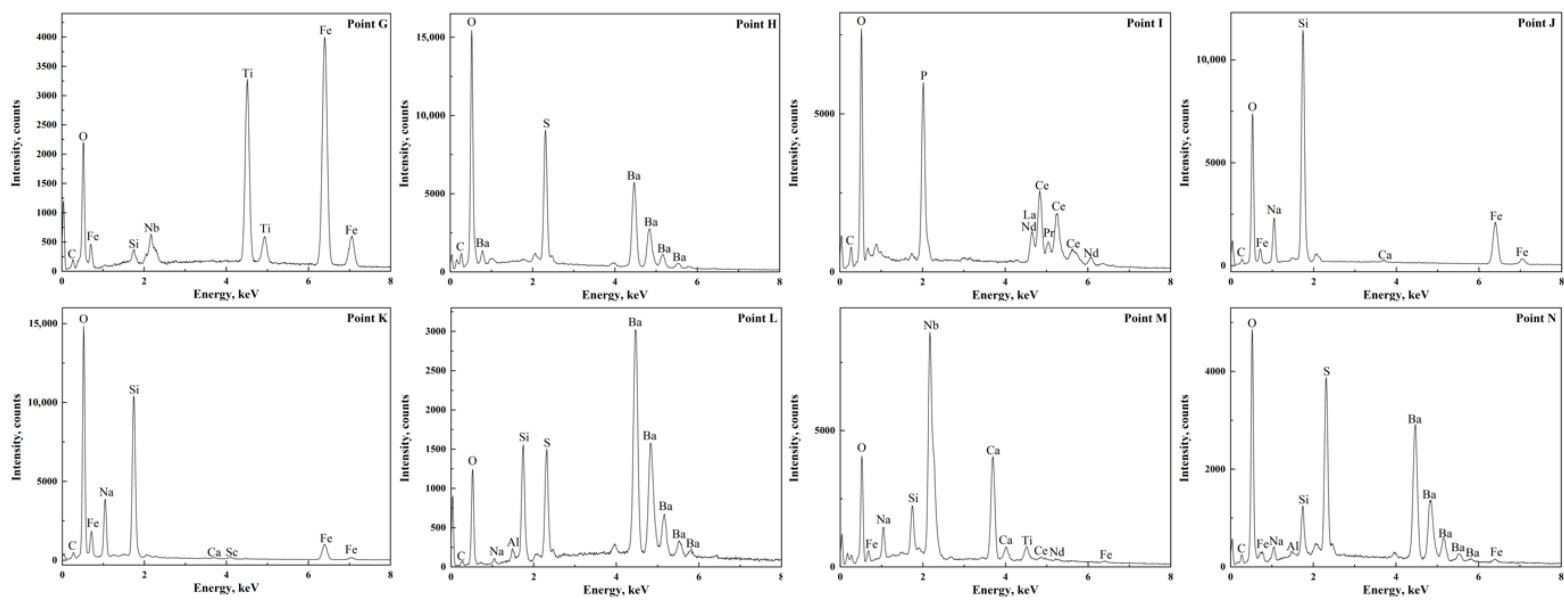

Figure 10. EDS analysis results of points in Figure 9.

Table 3. EDS analysis results of points in Figure 9 (wt.\%).

\begin{tabular}{ccccccccc}
\hline Element & Point G & Point H & Point I & Point J & Point K & Point L & Point M & Point N \\
\hline $\mathrm{C}$ & 1.38 & 4.63 & 3.60 & 3.78 & - & 0.86 & - & 2.38 \\
$\mathrm{O}$ & 10.78 & 25.00 & 17.32 & 25.65 & 45.41 & 5.56 & 27.28 & 17.92 \\
$\mathrm{~F}$ & - & - & - & - & - & - & 2.69 & - \\
$\mathrm{Na}$ & - & - & - & 7.34 & 11.21 & 0.33 & 2.74 & 1.01 \\
$\mathrm{Al}$ & - & - & - & - & - & 0.59 & - & 0.29 \\
$\mathrm{Si}$ & 0.45 & - & - & 26.02 & 23.81 & 5.65 & 3.02 & 2.85 \\
$\mathrm{P}$ & - & - & 11.68 & - & - & - & - & - \\
$\mathrm{S}$ & - & 12.93 & - & - & - & 5.99 & - & 12.32 \\
$\mathrm{Ca}$ & - & - & - & 0.40 & 0.41 & - & 16.70 & - \\
$\mathrm{Sc}$ & - & - & - & - & 0.57 & - & - & - \\
$\mathrm{Ti}$ & 20.90 & - & - & - & & - & 3.07 & - \\
$\mathrm{Fe}$ & 64.39 & - & - & 36.80 & 18.59 & 0.69 & 0.73 & 1.23 \\
$\mathrm{Nb}$ & 2.11 & - & - & - & - & - & 41.29 & - \\
\hline
\end{tabular}


Table 3. Cont.

\begin{tabular}{ccccccccc}
\hline Element & Point G & Point H & Point I & Point J & Point K & Point L & Point M & Point N \\
\hline $\mathrm{Ba}$ & - & 57.39 & - & - & - & 80.32 & - & 62.01 \\
$\mathrm{La}$ & - & - & 13.80 & - & - & - & - & - \\
$\mathrm{Ce}$ & - & - & 36.37 & - & - & - & 1.59 & - \\
$\mathrm{Pr}$ & - & - & 4.91 & - & - & - & - & - \\
$\mathrm{Nd}$ & - & - & 12.32 & - & - & - & 0.89 & - \\
\hline
\end{tabular}

\subsection{Kinetics Analysis of Mixed RE Mineral Decomposition}

The thermal decomposition of RE minerals in the tailings relates to polyphase solidstate reaction, which could be explained by Ginstling-Brundshtein model [20]. The kinetic mode is expressed as Equation (9):

$$
1-\frac{2}{3} x-(1-x)^{\frac{2}{3}}=k t
$$

where $x$ is the decomposition rate of RE minerals, $k$ represents the rate constants, and $\mathrm{t}$ is holding time (namely reaction time).

The experimental data from Figure 7 were used for the calculation with Equation (9), and the results were plotted in Figure 11. The linear results with the fit coefficients closing to 1.0 suggest that the thermal decomposition process of the RE minerals in tailings follows Ginstling-Brundshtein model. The values of $k$ were equal to the slope of the fitted line in Figure 11. Subsequently, the activation energy $E_{\mathrm{a}}$ was determined via plotting $\ln (k)$ versus inverse temperature 1/ $T$ according to the Arrhenius relationship given in Equation (10):

$$
\ln (k)=\ln \left(k_{0}\right)-\frac{E_{\mathrm{a}}}{R T}
$$

where $k$ is the rate constants, $k_{0}$ is the Arrhenius constant, $E_{\mathrm{a}}$ is the activation energy $(\mathrm{kJ} / \mathrm{mol}), R$ is the universal gas constant $(8.314 \mathrm{~J} /(\mathrm{K} \cdot \mathrm{mol})), T$ is the reaction temperature $(\mathrm{K})$.

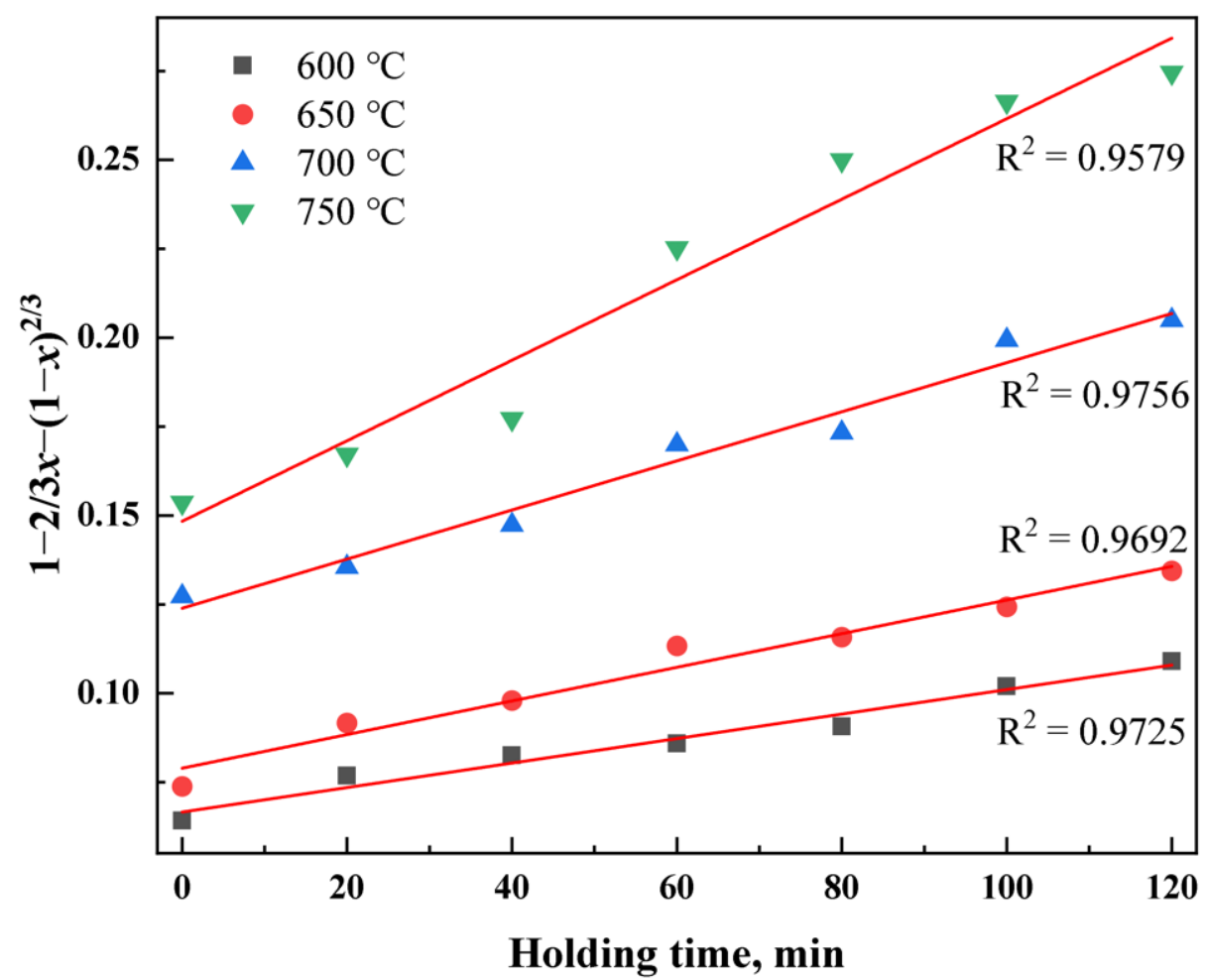

Figure 11. $1-2 / 3 x-(1-x)^{2 / 3}$ with respect to holding time for decomposition rate of RE minerals at various roasting temperature. 
As deduced from Figure 12, the apparent activation energy $E_{\mathrm{a}}$ was calculated as $58.28 \pm 6.12 \mathrm{~kJ} / \mathrm{mol}$. Empirically, the activation energy of the process controlled by diffusion is less than $13 \mathrm{~kJ} / \mathrm{mol}$. While the activation energy of the process controlled by chemical reaction is higher than $42 \mathrm{~kJ} / \mathrm{mol}$.

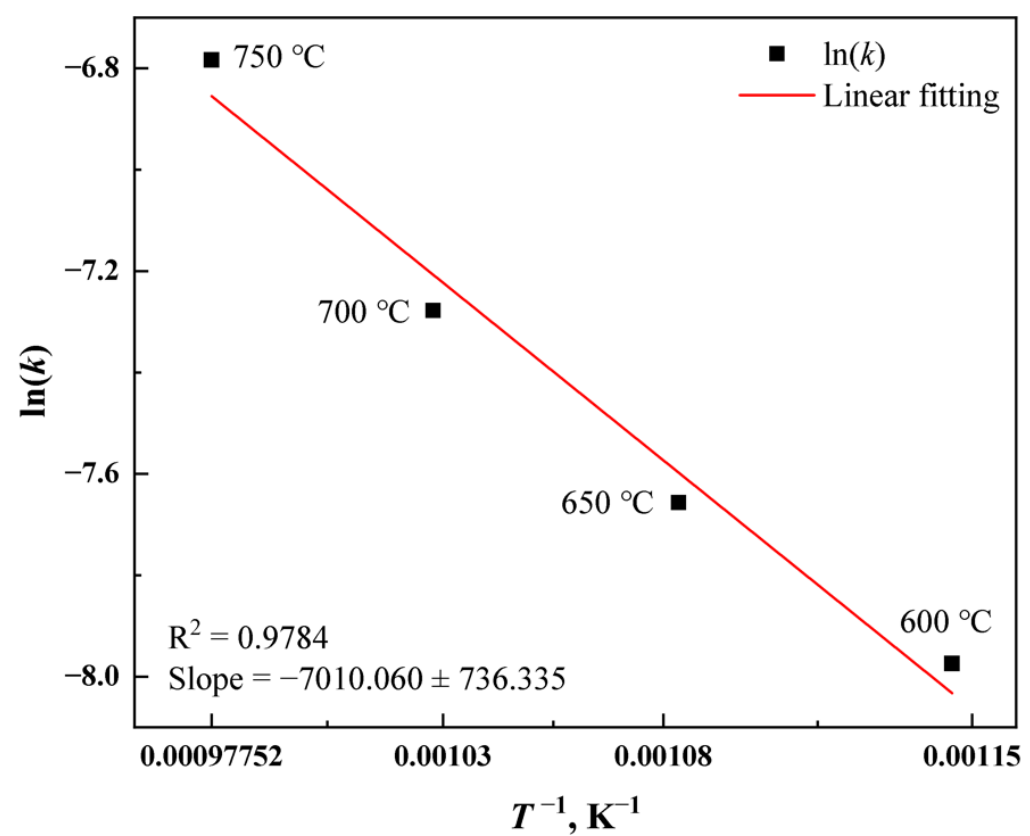

Figure 12. Arrhenius plot for decomposition rate of RE minerals.

For the process mutually controlled by diffusion and chemical reaction, the activation energy is in the range of 13-42 kJ/mol [10,15]. Apparently, the thermal decomposition of $\mathrm{RE}$ minerals in tailings with the addition of $\mathrm{MgO}$ is controlled by chemical reaction. This is consistent with the control mode between 600 and $700{ }^{\circ} \mathrm{C}$ for the decomposition of RE minerals in tailings with the addition of $\mathrm{CaO}$ demonstrated by Yuan et al. [10].

\section{Conclusions}

The effect of $\mathrm{MgO}$ on the thermal decomposition of RE minerals in tailings was experimentally investigated in this study. With the $\mathrm{MgO}$ dosage of $10 \mathrm{wt} . \%$, the decomposition rate of RE minerals increased to $98.09 \%$ at $750{ }^{\circ} \mathrm{C}$. The decomposing products were mainly RE oxides, thereby facilitating RE leaching process. The niobium minerals are not decomposed at all as the temperature rising to $750{ }^{\circ} \mathrm{C}$, resulting in the incomplete decomposition rate. The apparent activation energy was calculated as $58.28 \pm 6.12 \mathrm{~kJ} / \mathrm{mol}$, suggesting the decomposition of RE minerals with the addition of $\mathrm{MgO}$ was controlled by chemical reaction.

Author Contributions: Conceptualization, X.X. and Y.Z.; methodology, Y.Z. and S.S.; software, J.L. and G.C.; validation, G.C., J.L. and Y.Z.; formal analysis, Y.Z.; investigation, Y.Z. and S.S.; resources, X.X. and H.Y.; data curation, Y.Z. and S.S.; writing —original draft preparation, Y.Z.; writing-review and editing, Y.Z. and J.L.; visualization, Y.Z.; supervision, X.X. and H.Y.; project administration, X.X. and H.Y.; funding acquisition, X.X. and H.Y. All authors have read and agreed to the published version of the manuscript.

Funding: National Natural Science Foundation of China [grant number 51274061]; National Program on Key Basic Research Project of China [grant number 2012CBA01205].

Acknowledgments: Special thanks are due to the instrumental from Analytical and Testing Center, Northeastern University.

Conflicts of Interest: The authors declare no conflict of interest. 


\section{References}

1. Huang, X.; Zhang, Y.; Li, H. Development Trend and Research Progress of Rare Earth Extraction in China. Bull. Natl Nat. Sci. Found. China 2011, 25, 134-137.

2. Xu, G.X. Rare Earths, 2nd ed.; Metallurgical Industry Press: Beijing, China, 2012; Volume 1, ISBN 7-5024-1678-1.

3. Resende, L.V.; Morais, C.A. Study of the Recovery of Rare Earth Elements from Computer Monitor Scraps-Leaching Experiments. Miner. Eng. 2010, 23, 277-280. [CrossRef]

4. Savel'eva, I.L. The Rare-Earth Metals Industry of Russia: Present Status, Resource Conditions of Development. Geogr. Nat. Resour. 2011, 32, 65-71. [CrossRef]

5. Li, K.; Liang, T.; Wang, L.; Yang, Z. Contamination and Health Risk Assessment of Heavy Metals in Road Dust in Bayan Obo Mining Region in Inner Mongolia, North China. J. Geogr. Sci. 2015, 25, 1439-1451. [CrossRef]

6. Zhou, Y.; Yang, H.; Xue, X.; Yuan, S. Separation and Recovery of Iron and Rare Earth from Bayan Obo Tailings by Magnetizing Roasting and (NH4)2SO4 Activation Roasting. Metals 2017, 7, 195. [CrossRef]

7. Yu, X.-L.; Bai, L.; Wang, Q.-C.; Liu, J.; Chi, M.-Y.; Wang, Z.-C. Recovery of Rare Earths, Niobium, and Thorium from the Tailings of Giant Bayan Obo Ore in China. Metall. Materi. Trans. B 2012, 43, 485-493. [CrossRef]

8. Wang, L.; Liang, T. Accumulation and Fractionation of Rare Earth Elements in Atmospheric Particulates around a Mine Tailing in Baotou, China. Atmos. Environ. 2014, 88, 23-29. [CrossRef]

9. Xiaowei, H. Development Status and Research Progress in Rare Earth Hydrometallurgy in China. J. Chin. Rare Earth Soc. Chin. Ed. 2006, 24, 129.

10. Yuan, S.; Yang, H.; Xue, X.-X.; Zhou, Y. Kinetics of Roasting Decomposition of the Rare Earth Elements by CaO and Coal. Metals 2017, 7, 213. [CrossRef]

11. Chi, R.; Zhang, X.; Zhu, G.; Zhou, Z.A.; Wu, Y.; Wang, C.; Yu, F. Recovery of Rare Earth from Bastnasite by Ammonium Chloride Roasting with Fluorine Deactivation. Miner. Eng. 2004, 17, 1037-1043. [CrossRef]

12. Shi, W.; Zhu, G.; Hua, J.; Xu, S.; Chi, R. Recovery of RE from Baotou rare earth concentrate with chlorination roasting. Trans. Nonferrous Metals Soc. China 2003, 13, 438-442.

13. Zhu, G.; Chi, R.; Shi, W.; Xu, Z. Chlorination Kinetics of Fluorine-Fixed Rare Earth Concentrate. Miner. Eng. 2003, 16, 671-674. [CrossRef]

14. Cen, P.; Wu, W.; Bian, X. Thermodynamic Mechanism Analysis of Calcification Roasting Process of Bastnaesite Concentrates. Metall. Mater. Trans. B 2017, 48, 1539-1546. [CrossRef]

15. Xue, B.; Fengyun, Z.; Wenyuan, W. Kinetics of Mixed Rare Earths Minerals Decomposed by CaO with NaCl-CaCl2 Melting Salt. J. Rare Earths 2010, 28, 5.

16. Sadri, F.; Nazari, A.M.; Ghahreman, A. A Review on the Cracking, Baking and Leaching Processes of Rare Earth Element Concentrates. J. Rare Earths 2017, 35, 739-752. [CrossRef]

17. Carrillo García, A.; Latifi, M.; Chaouki, J. Kinetic Study of Calcination of a Rare Earth Ore. Hydrometallurgy 2021, 200, 105557. [CrossRef]

18. WU, W.; BIAN, X.; WU, Z.; SUN, S.; TU, G. Reaction Process of Monazite and Bastnaesite Mixed Rare Earth Minerals Calcined by CaO-NaCl-CaCl2. Trans. Nonferrous Metals Soc. China 2007, 17, 864-868. [CrossRef]

19. Zhang, B.; Xue, X.; Huang, X.; Yang, H.; Chen, G. Study on Recycling and Leaching Valuable Elements from Bayan Obo Tailings. Metall. Res. Technol. 2019, 116, 114. [CrossRef]

20. Espenson, J.H. Chemical Kinetics and Reaction Mechanisms; Citeseer: Princeton, NJ, USA, 1995; Volume 102. 